\title{
Cadmium Toxicity: Oxidative Stress, Inflammation and Tissue Injury
}

\author{
Sandra Concepcion Das ${ }^{1,2^{*}}\left(\mathbb{D}\right.$, Hamda A. Al-Naemi1 ${ }^{1,2}$ \\ ${ }^{1}$ Laboratory Animal Research Center, Qatar University, Doha, Qatar \\ ${ }^{2}$ Department of Biological \& Environmental Sciences, Qatar University, Doha, Qatar \\ Email: *sandradas@qu.edu.qa, ^halnaemi@qu.edu.qa
}

How to cite this paper: Das, S.C. and Al-Naemi, H.A. (2019) Cadmium Toxicity: Oxidative Stress, Inflammation and Tissue Injury. Occupational Diseases and Environmental Medicine, 7, 144-163. https://doi.org/10.4236/odem.2019.74012

Received: August 25, 2019

Accepted: October 14, 2019

Published: October 17, 2019

Copyright $\odot 2019$ by author(s) and Scientific Research Publishing Inc. This work is licensed under the Creative Commons Attribution International License (CC BY 4.0).

http://creativecommons.org/licenses/by/4.0/ (c) (i) Open Access

\begin{abstract}
Cadmium is a known environmental pollutant targeting various organs. Often implicated in cadmium toxicology is the formation of reactive oxygen species, overwhelming the free radical scavenging mechanisms and inducing oxidative stress. Acute cadmium intoxication has been shown to reduce antioxidant enzyme activity and induce oxidative stress. However, chronic intoxication has obscure outcomes in oxidative stress while the cell makes adjustments to overcome the toxicant load. Also linked with the occurrence of oxidative stress is inflammation. Stimulation of acute or chronic inflammation is mediated by different cascades. However, key events include activation of transcription factor, NF- $\kappa \mathrm{B}$ and release of pro-inflammatory cytokines. Both oxidative stress and inflammation are implicated simultaneously in pathogenesis and induction of multi-organ tissue damage under cadmium exposure. This article reviews the impact of acute and chronic cadmium intoxication on inducing oxidative stress, inflammation and thereby inflicting tissue damage.
\end{abstract}

\section{Keywords}

Cadmium, Inflammation, Tissue Injury

\section{Cadmium as an Environmental Pollutant}

Cadmium is naturally occurring element in the Earth's crust with concentrations of $0.1-0.5 \mathrm{ppm}$ in association with ores of zinc, lead and copper. It is a heavy metal that has various industrial applications with about 24,000 metric tons being produced yearly worldwide [1]. This production mainly caters to the manufacturing of nickel-cadmium batteries, pigments, chemical stabilizers, metallic coatings and alloys. In the environment, $\mathrm{Cd}$ is derived naturally and anthropo- 
genically, frequently circulating between three environmental compartments of the air, water and soil. A contributing factor to its circulation in the environmental compartments is its high persistence due to non-biodegradability. Additionally, the metal is reported to have a high rate of transfer from soil-to-plant, making it possible for $\mathrm{Cd}$ to enter the food chain [2].

Cadmium is considered to be a xenobiotic metal as it is known to be toxic to plants, animals and humans even at low concentrations and has no essential biological functions [3]. Owing to its ubiquity, toxicity and long biological half-life (ranging between 10 - 35 years) [4], its rising levels in the environment are cause for public health concern. For humans, Cd can enter the body by inhalation of tobacco smoke, ingestion of contaminated food and water, dermal absorption and occupational exposure. For non-occupationally exposed and non-smokers, the main route of exposure is via ingestion of Cd-contaminated food and water. The route of exposure impacts $\mathrm{Cd}$ absorption wherein inhalation contributes of up to $50 \%$, ingestion contributes to an estimated $10 \%$ and is nearly negligible by dermal contact [5]. The ingested amount can increase up to $20 \%$ based on the nutritional status of the individual [4]. Despite its industrial importance, recently, it is recognized as one among the 126 priority pollutants [6], a Class I carcinogen [7] and is considered an environmental pollutant and health toxicant [5] [8].

Tissue Cd concentrations vary based on the route, duration and dose of exposure. The primary sinks of $\mathrm{Cd}$ body burden are stored in the kidney and liver ranging from $50 \%-85 \%$ out of which $30 \%-60 \%$ is stored in the kidney alone. Recently, it has been estimated that dietary Cd exposure contributed to $0.2 \%$ of the global burden of chronic kidney disease [9]. Apart from the primary stores, Cd-induced damage has also been reported in brain [10], cardiovascular system [11] [12], nervous system [13], immune system [14], gut [15] and reproductive system [16] [17]. In addition to its ability to bioaccumulate, a relatively small fraction (0.007\%) of Cd is excreted from the body as urine and feces [4]. A well cited epidemiological example of Cd-induced intoxication is the case of the "Itai-itai" disease in Japan first identified in the 1960s and Cd-associated mortality is reported till date [18]. Various reviews discuss the oxidative mechanisms and the inflammatory properties of incited by $\mathrm{Cd}$ exposure separatelyhowever there is accumulating evidence of the interplay between oxidative stress and inflammation [19] [20] [21]. This review aims to provide an overview on the link between Cd-induced oxidative stress, Cd-induced inflammation while discussing its association with inflicted tissue injury as a result of Cd toxicity.

\section{Cadmium-Induced Oxidative Stress}

Pathologies of $\mathrm{Cd}$ intoxication has been associated with promoted oxidative stress [22]. Oxidative stress is characterized by an imbalance in the production of oxidants and antioxidants in the organ or the organism, favoring the former and causing cellular disruption [23]. It has been discussed that this imbalance may be a result of either overproduction of reactive oxygen species (ROS) and 
reactive nitrogen species (RNS) or weakening of the elimination of ROS by the oxidant defense mechanisms [24]. However, physiological amounts of ROS are required for normal cellular functions such as signal transduction, cell proliferation, gene expression and immune defense. Reactive oxygen species consist of various amounts of hydrogen peroxide $\left(\mathrm{H}_{2} \mathrm{O}_{2}\right)$, hydroxyl radical $(\mathrm{HO} \bullet)$, superoxide anions $\left(\mathrm{O}_{2}^{-}\right)$, peroxyl $(\mathrm{RO} \bullet)$ and alkoxyl radicals $(\mathrm{ROO} \bullet)$ whereas reactive nitrogen species (RNS) include nitric oxide radical (NO•), nitrogen dioxide radical $\left(\mathrm{NO}_{2} \bullet\right)$ and peroxynitrite $\left(\mathrm{ONOO}^{-}\right)$. Under normal physiological conditions, generation and elimination of these radicals are maintained under redox balance.

Redox homeostasis is mediated via Nrf2 and NF- $\kappa \mathrm{B}$ translocation [25], and enzymatic and non-enzymatic antioxidant defenses [26]. Enzymes of the antioxidant system that protect against ROS are superoxide dismutase, catalase and glutathione peroxidase (Figure 1). One of the main antioxidant enzymes is superoxide dismutase (SOD) which is a metallo-enzyme found in the mitochondria and cytosol that catalyze the conversion of oxygen radicals to hydrogen peroxide, $\mathrm{H}_{2} \mathrm{O}_{2}$ at a high reaction rate [26] [27]. The hydrogen peroxide produced as a result of SOD activity is detoxified by catalases and glutathione peroxidases. Catalases (CAT) are heme-containing enzymes that catalyze the breakdown of $\mathrm{H}_{2} \mathrm{O}_{2}$ into water and divalent oxygen. CAT activity is mainly localized in peroxisomes and in a lesser extent in the cytoplasm of erythrocytes, in the nucleus and

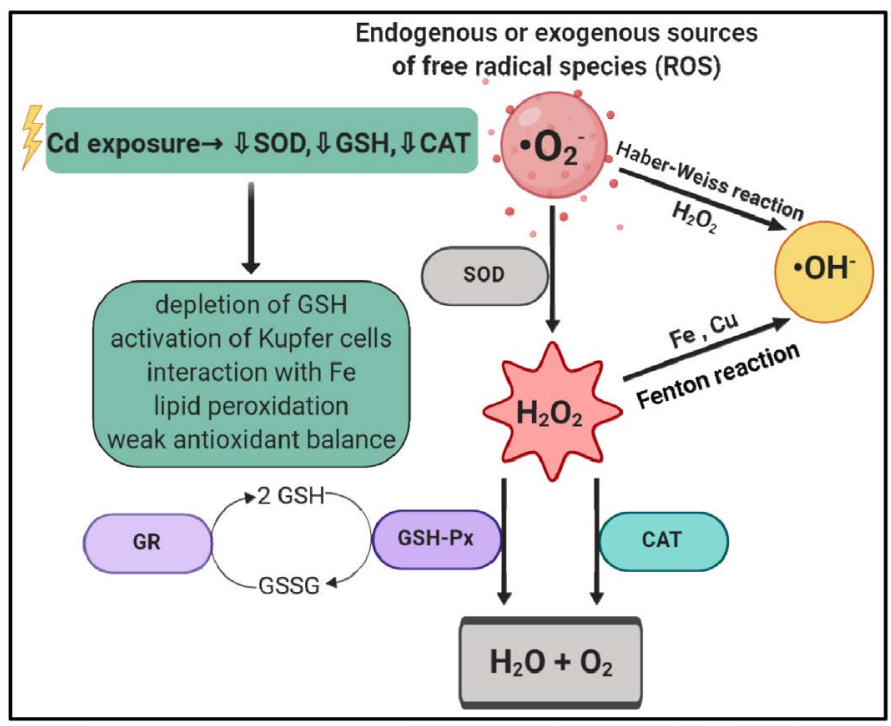

Figure 1. Illustration showing the reactions to maintain redox balance in the cells. Free radicals like superoxide anions generated by endogenous or exogenous sources is converted to hydrogen peroxide by superoxide dismutase (SOD). The hydrogen peroxide is further broken down to water and molecular oxygen by either catalase (CAT) or glutathione peroxidase (GSH-Px). Glutathione reductase (GR) and GSH-Px work together to maintain a balance in glutathione (GSH) and its reduced product (GSSG). The presence of cadmium in cells interferes with these reactions by decreasing SOD,GSH and CAT thereby producing $\mathrm{OH}$ radicals by Haber-Weiss and Fenton reactions and accumulating free radicals. Hence, inducing oxidative stress. (Created using biorender.com). 
in the mitochondria. While CAT is active in severe stress conditions, peroxidases (Px) are suggested to protect the cell during acute oxidative stress. Unlike CAT, Px detoxify $\mathrm{H}_{2} \mathrm{O}_{2}$ through the oxidation of other organic substrates. Glutathione peroxidases (GSH-Px) utilizes $\mathrm{H}_{2} \mathrm{O}_{2}$ to oxidize $\mathrm{GSH}$ to glutathione disulfide (GSSG). Another enzyme involved in the antioxidant defense system is glutathione reductase (GR) which reduces GSSG to GSH. Both GSH-Px and GR work together in the cells to maintain a steady state in the ratio of GSH to GSSG [28]. When the cells are under oxidative stress, the enzymes of the antioxidant defense system respond by altering their activity to overcome the oxidative stimuli. When the concentration of ROS exceeds the threshold such that it is not controlled by antioxidants like ascorbic acid and glutathione or radical scavenging enzymes like catalase, peroxidase and superoxide dismutase, oxidative damage to various biomolecules (proteins, lipids and DNA) may ensue consequently leading to cytotoxicity and genotoxicity [29]. Apart from the enzyme index, a key measure of oxidative stress is lipid peroxidation, as indicated by the concentrations of malondialdehyde (MDA), which may accumulate as a result of cell damage [30].

In response to Cd exposure, depending on the route of exposure various cellular defense mechanisms are activated to overcome the toxic effects of $\mathrm{Cd}$. Among the main defense mechanisms are the induction of metallothionein (MT) primarily in the kidney and liver, elevation in cellular glutathione and activation of antioxidant transcription factor Nrf2. These mechanisms are not "mutually exclusive" but may work together in a cohesive way to resist Cd-induced oxidative stress. Following exposure, Cd enters the blood stream via erythrocytes or albumin and undergoes hepatic conjugation where it complexes with MT to form Cd-MT which can be filtered out by the glomerulus, reabsorbed at the proximal tubule and distal tubule. After its entry into the tubular cell, lysosomes break the Cd-MT complex to free Cd. This free Cd initiates damage to the kidneys consequently inducing oxidative stress. Apart from this free Cd, ROS can also be produced when Fenton metals (like iron and copper) are displaced by Cd from MT or through the depletion of GSH [27]. Highly abundant in cells, GSH is a target of free Cd ions. Cd-induced depletion of the reduced GSH pool leads to the disruption of the redox balance leading to an oxidative environment. Hence, Cd-induced oxidative damage is considered to be a major mechanism rendering its toxicity to various organs by weakening the antioxidant mechanism.

Cadmium does not induce ROS production directly however, this xenobiotic metal could generate free radicals indirectly [27] [31]. The ensuing response to the oxidative stress is dependent on the duration of exposure - acute or chronic. In the case of acute $\mathrm{Cd}$ exposure, free radicals inclusive of superoxide anion, hydrogen peroxide, hydroxy radical and lipid radicals are generated. These Cd-induced generation of free radicals are mediated by indirect mechanisms such as depletion of glutathione, activation of Kupffer cells, inflammation and involvement of iron in the Fenton reactions [24] [32] [33]. However, in chronic 
exposure at environmentally relevant low doses, it is hypothesized that adaptive mechanisms are activated to overcome the Cd-induced ROS and oxidative stress such that when ROS generation overloads the antioxidant defense system, lipid peroxidation and oxidative damage begins [28].

A study comparing the effects of single Cd administration $(30 \mathrm{mg} / \mathrm{kg}$ b.w. orally and $1.5 \mathrm{mg} / \mathrm{kg}$ b.w. intraperitoneally) on parameters of oxidative stress in liver of Wistar rats reported an increase of superoxide anion and MDA levels with a negative impact on SOD activity [34]. The authors demonstrate the crucial role of the route of administration in the potency of $\mathrm{Cd}$ such that pronounced effects were observed in parameters of oxidative stress in rats treated via intraperitoneal administration. Also reported in the study was the higher accumulation of $\mathrm{Cd}$ in the blood and liver $(77.42 \mu \mathrm{g} / \mathrm{L}$ and $14.18 \mu \mathrm{g} / \mathrm{g}$ wet weight, respectively) of rats intoxicated intraperitoneally compared to both control and orally intoxicated groups [34]. The authors concluded that acute Cd intoxication via oral or intraperitoneal administration results in promotion of rapid lipid peroxidation in liver accompanied by elevated MDA levels. Another study evaluating the effect of chronic oral Cd exposure (3, 10 and $30 \mathrm{mg} / \mathrm{L}$ ) for 7 and 21 days in male mice reported a significant increase in hepatic activities of MDA, SOD, GSH-Px, CAT and glutathione-S-transferase (GST) with a significant decrease in GSH, after treatment with $30 \mathrm{mg} / \mathrm{L}$ for 21 days [35]. In corroboration with the pattern of activity after treatment with $30 \mathrm{mg} / \mathrm{L}$ for 21 days, the gene expression for hepatic SOD, CAT, GSH-Px and GR were also increased. The study also showed that in response to $\mathrm{Cd}$ exposure, an inflammatory response was triggered not only at the physiological level but also on the transcriptional level suggesting that $\mathrm{Cd}$ exposure has the potential to induce immunotoxicity accompanied with oxidative stress in the liver of mice [35].

A study exploring the nephrotoxic effect of intraperitoneal acute administration of Cd (2.5 and $5 \mathrm{mg} / \mathrm{kg}$ b.w.) in male rats reported a significant effect on lipid peroxidation and oxidative stress [36]. The authors reported an increase in renal MDA at both doses however, a significant decrease in renal CAT, SOD and GSH-Px activities was observed at the dose of $5 \mathrm{mg} / \mathrm{kg}$ b.w. compared to the control and $2.5 \mathrm{mg} / \mathrm{kg}$ b.w. The activities of antioxidant enzymes has been shown to decrease on acute exposure to $\mathrm{Cd}$ whereas chronic exposure causes an increase in the antioxidant enzymes due to cellular adjustments to overcome the Cd intoxication [30]. Table 1 summarizes the impact of $\mathrm{Cd}$ exposure at variable doses and different biological setups. These reports demonstrate that at acute or chronic doses of $\mathrm{Cd}$ exposure, the antioxidant mechanism is weakened, and the system is overwhelmed with oxidative stress.

\section{Cadmium-Induced Inflammation}

Inflammation and oxidative stress are closely linked in pathophysiological outcomes wherein one may be induced by the other (Figure 2). Inflammation is described as a complex interaction in the vascularized connective tissues as a response to exogenous and endogenous stimuli with the goal to clear out both the 
Table 1. Summary of impact of cadmium exposure to weakened antioxidant mechanism inducing oxidative stress.

\begin{tabular}{|c|c|c|c|}
\hline Dose and duration of Cd administered & Tissue/Animal & Response to Cd exposure & Reference \\
\hline $0.1,0.5,1.0$ and $2.0 \mathrm{mg} / \mathrm{L}$ for 30 days & $\begin{array}{l}\text { Male Swiss } \\
\text { albino mice }\end{array}$ & $\begin{array}{l}\text { Dose-dependent increase of ROS in blood stream } \\
\text { Reduced CAT, SOD and GSH-Px enzyme activity } \\
\text { in liver, kidney, spleen, testis and brain }\end{array}$ & [10] \\
\hline $\begin{array}{l}15 \mathrm{mg} / \mathrm{kg} \text { b.w./day single dose } \\
15 \mathrm{mg} / \mathrm{kg} \text { b.w./day for } 60 \text { days }\end{array}$ & $\begin{array}{l}\text { Male Wistar } \\
\text { albino rats }\end{array}$ & $\begin{array}{l}\text { Significant increase in CAT and MDA levels in } \\
\text { erythrocytes compared to control group } \\
\text { Significant increase in CAT, GSH-Px, SOD and MDA } \\
\text { in erythrocytes compared to control group }\end{array}$ & [11] \\
\hline $30 \mathrm{mg} / \mathrm{kg}$ b.w. for 21 days & Male Wistar rats & $\begin{array}{l}\text { Significant increase in MDA levels in blood stream } \\
\text { Significant reduction in GSH, SOD and CAT levels in blood stream }\end{array}$ & [37] \\
\hline 15 and $100 \mathrm{ppm}$ for 60 days & Male Wistar rats & $\begin{array}{l}\text { Increased CAT and SOD levels in heart tissue at } 15 \mathrm{ppm} \text { dose } \\
\text { Significant increase in CAT levels in heart tissue at } 100 \mathrm{ppm}\end{array}$ & [38] \\
\hline $40 \mathrm{mg} / \mathrm{L}$ for 6 weeks & Male albino rats & $\begin{array}{l}\text { Significant decreases of CAT, SOD and reduced GSH in } \\
\text { plasma significantly reducing the total antioxidant capacity } \\
\text { Significant increase in MDA levels in plasma }\end{array}$ & [39] \\
\hline $5 \mathrm{mg} / \mathrm{kg}$ b.w. for 30 days & $\begin{array}{l}\text { Adult male } \\
\text { albino Wistar mice }\end{array}$ & $\begin{array}{l}\text { Liver CAT, SOD, GRx and GST were significantly } \\
\text { reduced while liver MDA was significantly increased }\end{array}$ & [40] \\
\hline $50 \mathrm{mg} / \mathrm{L}$ for 12 weeks & Male Wistar rats & $\begin{array}{l}\text { Decreased activity of SOD and GPx while reducing } \\
\text { levels of GSH and total antioxidant capacity in liver tissues }\end{array}$ & [41] \\
\hline 10 and $50 \mathrm{ppm}$ for 30 days & $\begin{array}{l}\text { Female } \\
\text { Sprague-Dawley rats }\end{array}$ & $\begin{array}{l}\text { Elevated blood plasma MT levels till } 7 \text { days after exposure } \\
\text { and reduced blood plasma MT levels in the following } 2 \text { weeks. }\end{array}$ & {$[42]$} \\
\hline
\end{tabular}

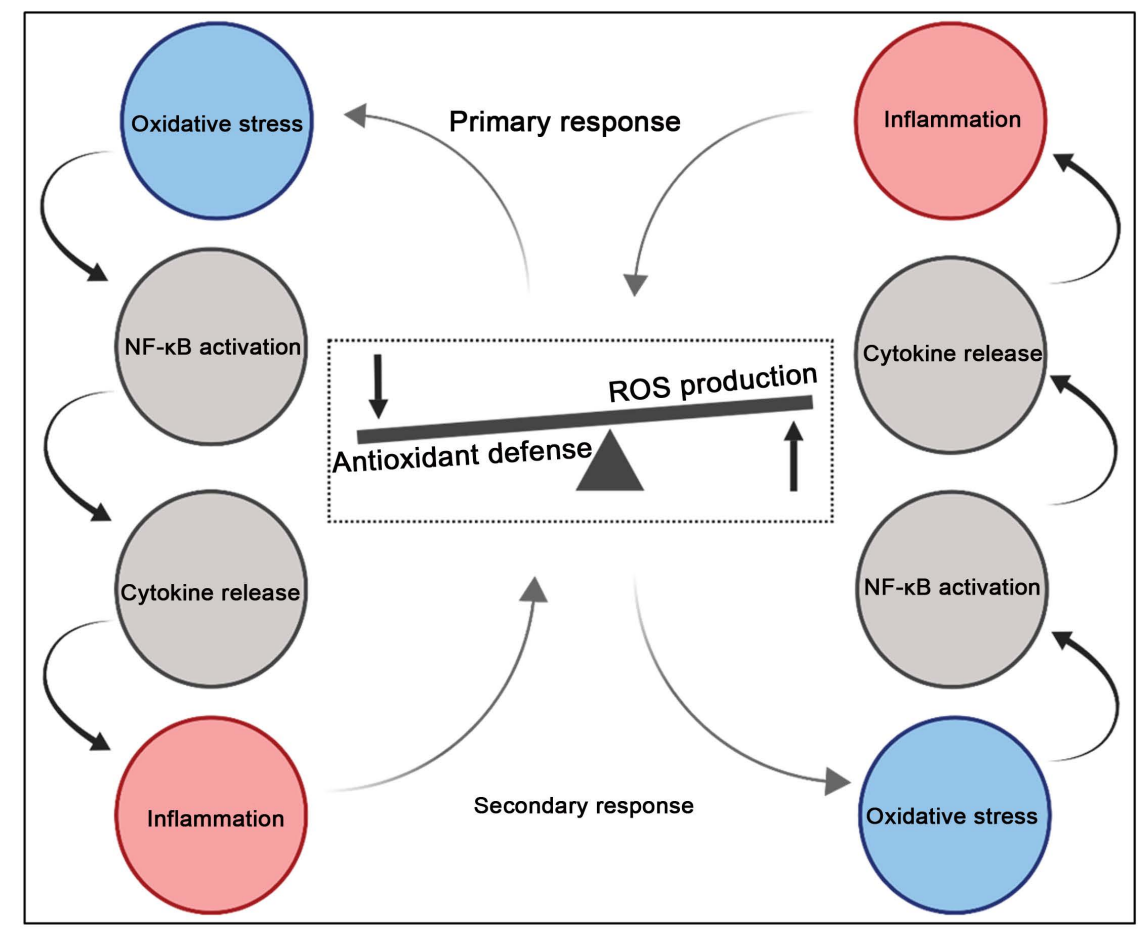

Figure 2. Illustration showing the interdependence of oxidative stress and inflammation induced by exposure to cadmium. Primary response to presence of cadmium results in oxidative stress or inflammation which may lead to the other as a secondary response. Key events include weakened antioxidant defense, elevated ROS production, activated NF- $\kappa \mathrm{B}$ and release of cytokines. (Created using biorender.com). 
initial cause of the cellular injury and the consequences of the injury [43]. When an inflammatory response is activated by injurious stimuli, the response is triggered through two stages- acute and chronic- and each is mediated by a different cascade. Acute inflammation has different everts that involve increase in vascular permeability and recruitment of white blood cells. Cellular events are mediated by cellular adhesion molecules and integrins expressed on endothelium cells and white blood cells, respectively. The recruited cells produce cytokines (i.e. IL-1 $\beta$, TNF- $\alpha$, IL- 6 and IL-8) that promote cytokine cascades and further the migration and activation of leucocytes to the site of injury [44] [45]. Failure of successful resolution of the inciting agent from the system, shifts the acute response towards a more complex process leading to the chronic response. Chronic inflammation is characterized by the infiltration of mononuclear cells like monocytes and lymphocytes, proliferation of fibroblasts, formation of connective tissue and presence of collagen fibers. Chronic inflammation is mediated by IL-12, IL-4, TGF- $\beta$ that regulate the activation and differentiation of T-lymphocytes [44]. The presence of T-lymphocytes and B-lymphocytes is a likely indicator of the presence of a persistent inciting agent [44]. With chronic inflammation, continued inflammatory cell recruitment that becomes unregulated inflicts tissue damage that is mediated by nitrogen species, proteases and ROS released from inflammatory cells [44] [45].

At the site of inflammation, the inflammatory cells release several reactive species leading to exaggerated oxidative stress. Moreover, ROS indirectly generated by inflammatory cells (besides direct oxidative stress) can also induce and amplify signaling cascades that enhances proinflammatory gene expression [21]. ROS-induced activation of enzymes that facilitate phosphorylation leads to the activation of transcription factors, which in turn trigger the generation of pro-inflammatory cytokines and chemokines. The participation of several transcription factors (NF- $\kappa \mathrm{B}, \mathrm{AP}-1$ ), adhesion molecules (ICAM-1, PECAM-1, VCAM-1), secretion of several chemokines (IL-8 and its homolog MIP-2, MCP-1), enzymes (MPO, iNOS, MMPs, COX-2), reactive species (ROS, RNS) and chemical mediators (NO, complement components) have been implicated in the process of inflammatory cellular infiltration, thereby inducing tissue damage and oxidative stress [21] [46]. Thus, both oxidative stress and inflammation are implicated simultaneously in pathogenesis. Table 2 shows a summary of inflammatory cytokines and their function and their alterations under $\mathrm{Cd}$ exposure.

\subsection{Activation of NF- $\kappa \mathrm{B}$ by Cadmium}

An important player in inflammation is the transcription factor, nuclear factor- $\kappa \mathrm{B}$ (NF- $\kappa \mathrm{B}$ ), which regulates the expression of pro-inflammatory genes including cytokines, enzymes, adhesion molecules and receptors that play a role in leukocyte recruitment and cell survival [62]. The activation of NF- $\kappa \mathrm{B}$ is a strong driver of chemokine production as it propagates the pro-inflammatory cascade [44]. Briefly, NF- $\kappa$ B is activated in response to a signaling cascade stimulated by 
Table 2. Summary of response of important inflammatory cytokines, their function and their altered response to cadmium treatment. The symbols in this table represent $\uparrow:$ increased, $\downarrow$ : decreased, $\leftrightarrow$ : no change observed.

\begin{tabular}{|c|c|c|c|}
\hline $\begin{array}{l}\text { Inflammatory } \\
\text { cytokine }\end{array}$ & Source & Function & Response to Cd exposure \\
\hline $\begin{array}{l}\text { Interleukin-8 } \\
\qquad(\text { IL-8) }\end{array}$ & Monocytes and macrophages [47] & $\begin{array}{l}\text { Pro-inflammatory chemotactic } \\
\text { factor that promotes the } \\
\text { directional migration of } \\
\text { neutrophils, basophils } \\
\text { and T-lymphocytes [48] }\end{array}$ & $\begin{array}{l}\uparrow \text { release in hum an astrocytes } \\
\text { through MAPK phosphorylation [49] } \\
\uparrow \text { secretion by primary human } \\
\text { airway epithelial cells in dose- and } \\
\text { time-dependent manner independent } \\
\text { of NF- } \mathrm{\kappa B}[50]\end{array}$ \\
\hline $\begin{array}{l}\text { Interleukin-6 } \\
\quad \text { (IL-6) }\end{array}$ & $\begin{array}{l}\text { Macrophages, dendritic cells, } \\
\text { T-cells, B-cells, endothelial cells, } \\
\text { astrocytes, microglia and neurons [51] }\end{array}$ & $\begin{array}{l}\text { Can have both pro-inflammatory } \\
\text { and anti-inflammatory action } \\
\text { depending on its level of } \\
\text { expression [52] } \\
\text { Important in T-cell and B-cell } \\
\text { differentiation as well as } \\
\text { acute-phase response in liver [51] }\end{array}$ & $\begin{array}{l}\uparrow \text { release in hum an astrocytes through } \\
\text { MAPK phosphorylation and } \\
\text { activation of NF- } \mathrm{kB}[49] \\
\uparrow \text { significant release in heart of male } \\
\text { rats treated with } 5 \mathrm{mg} / \mathrm{kg} \text { b.w. } \\
\text { for } 4 \text { weeks [53] } \\
\uparrow \text { secretion by primary hum an } \\
\text { airway epithelial cells [50] } \\
\downarrow \text { secretion by murine macrophages } \\
\text { treated with } 0.1 \mu \mathrm{M} \text { and } 10 \mu \mathrm{M} \text { Cd [54] } \\
\uparrow \text { levels in plasma of rats treated with } \\
40 \mathrm{mg} / \mathrm{L} \text { for } 6 \text { weeks [39] }\end{array}$ \\
\hline $\begin{array}{l}\text { Interleukin-1 } \\
\text { beta }(\mathrm{IL}-1 \beta)\end{array}$ & $\begin{array}{l}\text { Macrophages, microglia, } \\
\text { B-cells, monocytes, fibroblasts } \\
\text { and dendritic cells [51] }\end{array}$ & $\begin{array}{l}\text { Pro-inflammatory mediator of } \\
\text { innate immune response, critical } \\
\text { for activation of macrophages and } \\
\text { microglia, maturation of B-cell, } \\
\text { stimulation of T-cells and } \\
\text { activation of natural killer cells [51] }\end{array}$ & $\begin{array}{l}\leftrightarrow \text { Secretion by murine macrophages } \\
\text { treated with } 0.1 \mu \mathrm{M} \mathrm{Cd}[54] \\
\uparrow \text { secretion (3-fold) by murine } \\
\text { macrophages treated with } 10 \mu \mathrm{M} \mathrm{Cd}[54] \\
\downarrow \text { mRNA expression but } \\
\uparrow \text { release in primary alveolar } \\
\text { macrophages after Cd exposure [55] }\end{array}$ \\
\hline $\begin{array}{l}\text { Interleukin-10 } \\
\quad(\mathrm{IL}-10)\end{array}$ & $\begin{array}{l}\text { T-cells, monocytes, stimulated } \\
\text { macrophages, subsets of } \\
\text { dendritic cells, some granulocytes, } \\
\text { epithelial cells and tumor cells [56] }\end{array}$ & $\begin{array}{l}\text { Anti-inflammatory action by } \\
\text { inhibiting the release of } \\
\text { proinflammatory mediators [57] }\end{array}$ & $\begin{array}{l}\downarrow \text { secretion by murine macrophages } \\
\text { treated with } 0.1 \mu \mathrm{M} \text { and } 10 \mu \mathrm{M} \mathrm{Cd}[54]\end{array}$ \\
\hline $\begin{array}{l}\text { Interleukin-17 } \\
\quad(\mathrm{IL}-17)\end{array}$ & $\begin{array}{l}\text { T-helper cells, mast cells, } \\
\text { macrophages and eosinophils [51] }\end{array}$ & $\begin{array}{l}\text { Pro-inflammatory cytokine } \\
\text { involved in recruitment of } \\
\text { intracellular adaptor proteins and } \\
\text { downstream activation of } \\
\text { NF- } \kappa B \text { [58] }\end{array}$ & $\begin{array}{l}\uparrow \text { mRNA levels with in protein } \\
\text { product concentrations in } \\
\text { spleen of rats [59] }\end{array}$ \\
\hline $\begin{array}{l}\text { Tumor necrosis } \\
\text { factor-alpha } \\
\text { (TNF- } \alpha \text { ) }\end{array}$ & $\begin{array}{l}\text { Activated macrophages in response } \\
\text { to injurious stimuli [57] }\end{array}$ & $\begin{array}{l}\text { Pro-inflammatory mediator of } \\
\text { local and systemic inflammation } \\
\text { by amplifying and prolonging } \\
\text { inflammatory response by } \\
\text { activating cells to release } \\
\text { cytokines and mediators [57] }\end{array}$ & $\begin{array}{l}\uparrow \text { significant release in heart of male } \\
\text { rats treated with } 5 \mathrm{mg} / \mathrm{kg} \text { b.w. } \\
\text { for } 4 \text { weeks [53] } \\
\uparrow \text { levels in plasma of rats treated with } \\
40 \mathrm{mg} / \mathrm{L} \text { for } 6 \text { weeks [39] } \\
\downarrow \text { mRNA expression but } \\
\uparrow \text { release in primary alveolar } \\
\text { macrophages after Cd exposure [55] }\end{array}$ \\
\hline $\begin{array}{l}\text { Transforming } \\
\text { growth factor-beta } \\
\text { (TGF- } \beta)\end{array}$ & $\begin{array}{l}\text { Widely distributed including epithelial, } \\
\text { endothelial, hematopoietic, } \\
\text { neuronal and connective tissue cells [60] }\end{array}$ & $\begin{array}{l}\text { Pro-fibrotic cytokine crucial in } \\
\text { cell growth, apoptosis, } \\
\text { differentiation, proliferation, } \\
\text { migration, extracellular matrix } \\
\text { production, immune regulation, } \\
\text { wound healing and } \\
\text { inflammation [60] }\end{array}$ & $\begin{array}{l}\leftrightarrow \text { mRNA levels in human bronchial } \\
\text { cells treated with } 10 \mu \mathrm{M} \mathrm{Cd} \text { while } \\
\downarrow \text { mRNA levels in human bronchial } \\
\text { cells treated with } 20 \mu \mathrm{M} \mathrm{Cd} \\
\uparrow \text { mRNA levels of receptors in human } \\
\text { bronchial cells treated with } \\
10 \text { and } 20 \mu \mathrm{M} \mathrm{Cd}[61]\end{array}$ \\
\hline
\end{tabular}


cytokines at the site of damage. This activation promotes macrophage relocalization to and activation at the site of damage followed by a signaling cascade to augment macrophage activation and recruitment to the site in an effort to resolve the damage and terminate the inflammatory response. Chronic activation of NF- $\kappa \mathrm{B}$ accompanied with prolonged macrophage activation has been associated with disease pathogenesis [63] [64] [65]. Hence, disruption of NF- $k B$ function is critical to numerous disease pathogenesis. The most canonical pathway observed for activation of NF- $\kappa \mathrm{B}$ is induced in response to cellular stresses and stimuli. Metal-induced ROS is also known to activate NF- $\kappa$ B due to its redox-sensitivity transactivating various genes involved in inflammatory response [66] [67] [68]. During an inflammatory response, activation of NF- $\kappa \mathrm{B}$ antagonizes apoptosis involving the suppression of the Jun N-terminal kinase (JNK) cascade [69]. Several studies have confirmed that Cd activates the inflammatory response by upregulating the NF- $\kappa \mathrm{B}$ protein and downregulating anti-inflammatory protein expression [12] [19] [54]. A study showed that Cd-treated ( $5 \mathrm{mg} / \mathrm{kg}$ b.w. for 4 weeks) rats had significantly increased the protein levels of $\mathrm{NF}-\kappa \mathrm{B}$ subunit compared to the control group [53]. It is intriguing that activated NF- $\kappa \mathrm{B}$ signaling is known to cross-talk with the unfolded protein response (UPR) in Cd-induced apoptosis [70]. Moreover, it was demonstrated that low dose $\mathrm{Cd}(4 \mu \mathrm{M})$ stimulated the activation of the JNK pathway while inhibiting the NF- $\kappa \mathrm{B}$ pathway significantly playing an essential role in the survival of Cd-exposed human renal glomerular endothelial cells (HRGECs) [71]. Taken together, this demonstrates the role of activation or inactivation of NF- $\kappa \mathrm{B}$ in determining the survival of the cell mediated by cross talk with the JNK pathway.

\subsection{Cadmium-Induced Cytokine Release}

IL-8 is a key mediating chemoattractant in recruitment of neutrophils in acute inflammation. It is has been established that NF- $\kappa$ B is one of the crucial factors that regulate the gene expression of IL-8 [72]. Cd has been identified as a strong activator of IL-8 in an NF- $\kappa$ B-independent but Erk1/2-dependent pathway, a mitogen-activated protein kinases (MAPKs) cascade often involved in proinflammatory signaling, in vitro in lung epithelial cells and in vivo in mouse lungs [50]. In this study, exposure of human airway epithelial cells to Cd $(2 \mu \mathrm{M}$ and 5 $\mu \mathrm{M})$ promotes a unique inflammatory cytokine response consisting of IL- 8 but not IL- $1 \beta$ or TNF- $\alpha$. Interestingly, the outcomes of this study show that Cd can induce unique signature inflammatory responses consisting of IL- 8 and IL- 6 but not IL- $1 \beta$ or TNF- $\alpha$, which is conserved in vitro and in vivo [50]. Additionally, the immunomodulatory potential of Cd was shown in murine RAW 264.7 macrophages such that $\mathrm{Cd}(10 \mu \mathrm{M})$ highly upregulated the expression of interleukin, IL- $1 \beta$ and chemokine, CXCL1 and down regulated the anti-inflammatory cytokines IL-6 and IL-10 [54]. This may explain the elevated risk of chronic inflammation by long term $\mathrm{Cd}$ exposure following bacterial infection.

Djokic et al. noted that administration of a sublethal dose of Cd $(1 \mathrm{mg} / \mathrm{kg}$ b.w. for $48 \mathrm{~h}$ ) differentially decreases the levels of mRNA for IL-1 $\beta$, TNF- $\alpha$ and IL-6 
on peripheral blood polymorphonuclear (PMN) cells of rats [73]. In this study, an increase in plasma levels of TNF- $\alpha$ indicated a systemic inflammation which may be result of Cd-injured tissues. Furthermore to the pro-inflammatory effects of $\mathrm{Cd}$, it has been illustrated that $\mathrm{Cd}$ activates granulocytes and primes them for oxidative activity. A later study by Djokic et al., reported differential effects of a single sub-lethal Cd dose (1 mg/kg b.w.) on rat PMN cell biology [74]. While there was a limited effect of high dose $\mathrm{Cd}$ on the spontaneous production of TNF- $\alpha$ despite an increase in the basal mRNA level, there seemed a tendency for decreased spontaneous production of IL- 6 with a decrease in mRNA levels. In contrast to the decrease of mRNA expression of TNF- $\alpha$ and IL- 6 , that of IL- $1 \beta$ increased. The authors highlight that the differential effects on the production of a specific inflammatory cytokine can be attributed to the differences in Cd doses.

A suggested proinflammatory target of $\mathrm{Cd}$ in the spleen is IL-17 as evidenced by dose-dependent increase in IL-17 mRNA expression [59]. A study examining the impact of $\mathrm{Cd}$ at 5 and $50 \mathrm{ppm}$ on the immune reactivity of the gut in rats showed an increase in the levels of IL-17 hinting towards intestinal inflammation that was suggested to originate from cytokine-producing infiltrated leukocytes [75]. In the same study, elevated levels of TNF- $\alpha$ at 5 ppm and IL-1 $\beta$ at both doses was reported. The elevations in these cytokines are characteristic innate proinflammatory reactions to $\mathrm{Cd}$ intake in rats. The effect of oral exposure of $\mathrm{Cd}(5 \mathrm{ppm}$ and $50 \mathrm{ppm})$ on the immunity of the skin presented a dose-dependent oxidative stress and resulted in inflammation with an elevation in production of IL- $1 \beta$, IL- 6 and TNF- $\alpha$ in the epidermis [76].

A considerable amount of published literature into the pro-inflammatory effect of Cd reported the production and upregulation of IL-6, TNF- $\alpha$ and IL- $1 \beta$ in vivo and in vitro. A traditional marker of inflammation, IL-6, is an important pro-inflammatory cytokine that promotes inducing acute phase proteins and may also mediate the transition from acute to chronic inflammation [55]. TNF- $\alpha$ is a cytokine produced by activated macrophages in response to injurious stimuli. IL- $1 \beta$ is expressed by a wide range of cells that play a role in the activation of NF- $\kappa \mathrm{B}$ cascade and hence the induction of pro-inflammatory cytokines and chemokines [51]. The production of these above-mentioned cytokines might play a role in amplifying the inflammatory process in the tissue undergoing oxidative stress (Figure 1). Interestingly, with the accumulating reports of the pro-inflammatory effects of $\mathrm{Cd}$, there is also a contradiction in evidences regarding its immunomodulatory effect. In the context of chronic inflammation, an in vivo study testing the effect of low dose intra-articular Cd injection on induced arthritis rat joints showed that Cd-injection improved arthritis in the joints by reducing inflammation [77]. Results show a reduction of IL-6 production by synergistic action between IL-17 and TNF- $\alpha$ with no induction of local inflammation and limited deposition of $\mathrm{Cd}$ in the liver suggesting a safe risk/benefit ratio without inducing toxic effects on other organs [77]. Further to this study, it was demonstrated that the anti-inflammatory effect of $\mathrm{Cd}$ on the synoviocytes was reversed by the presence of zinc that competes with $\mathrm{Cd}$ for the 
non-selective transporter, ZIP-8 [78]. An early human study suggested that Cd may hold anti-inflammatory properties such that the metal suppresses inflammation by downregulating pro-inflammatory genes and thereby inhibiting infiltration into the vessel wall [79] [80]. It has also been shown that Cd significantly inhibited the production of TNF- $\alpha$ and IFN- $\gamma$ [80] [81]. A suggested mechanism is by dysregulating the gene expression of these cytokines caused by interfering with cellular signaling [81]. A key point to the differential effects of $\mathrm{Cd}$ is the use of different doses and biological systems that may have different response mechanisms to overcome the Cd load.

\section{Cadmium-Induced Tissue Injury}

Cells undergoing prolonged oxidative stress and inflammation may consequently lead to tissue injury [46]. Various studies have reported Cd-induced tissue injury in different organ systems evaluated by histopathological techniques. As mentioned previously, major targets of Cd toxicity are the liver and kidneys. A study examining the structural changes in adult rat liver following chronic subcutaneous Cd treatment $(2.5 \mathrm{mg} / \mathrm{kg}$ b.w. and $5 \mathrm{mg} / \mathrm{kg}$ b.w. for 45 days) reported biochemical, histopathological and histochemical aberrations to the liver [82]. The authors reported displaced lesions varying from hydropic degeneration to cellular necrosis and dilatation and congestion of majority of the portal vein radicals. Additionally, the extent of damage seemed to be time and dose-dependent. Promisingly, mild recovery was reported in specimens examined one month after Cd withdrawal manifested by significant increase in the number of binucleated cells and von Kupffer cells hyperplasia which phagocytosed the necrotic debris [82]. However, the degenerative changes such as pyknosis, karyolysis and single cell hepatocyte necrosis were still noticeably apparent. In another study, a histopathological evaluation of biopsied liver of male Wistar rats treated with $\mathrm{Cd}$ at a higher dose $(50 \mathrm{mg} / \mathrm{kg}$ b.w.) for 12 weeks showed alteration in hepatocellular integrity including hepatocellular degeneration, portal vein dilation and fibrotic changes relative to the control group [41].

A multi-organ investigative study by El-Refaiy and Eissa reported severe histopathological changes in the hepatic, renal, lung and testicular tissues of rats treated with $3 \mathrm{mg} \mathrm{Cd} / \mathrm{kg}$ b.w. for 2 months [83]. These histopathological changes were accompanied with substantial changes in the levels of biomarkers of oxidative stress, activities and levels of antioxidant enzymes. Liver damage was indicated by loss of normal hepatic architecture with fatty droplets, focal necrosis with infiltration of inflammatory cells, pyknotic nuclei, karyolysis, proliferation of Kupffer cells and bile ductless. Also, collagen fibers were reported to be increased in between hepatocytes, around the central vein and in the portal region [83]. These hepatocellular alterations could be a consequence of formation of highly reactive radicals and subsequent $\mathrm{Cd}$-induced lipid peroxidation. In the same study, glomerular and tubular changes inducing nephrotoxicity-shrinking and degeneration of the glomeruli and pyknosis and vacuolation of cytoplasm of tubules, multiple foci hemorrhage and congestion of blood vessels- were ob- 
served in the Cd treated rats. These lesions was accompanied with increased collagen fibers in the glomerular tuft, in between the renal tubules and around blood vessels. Another study reported glomerular swelling and focal tubular degeneration in kidneys of mice treated with a sub-chronic dose of $50 \mu \mathrm{g} \mathrm{Cd} / \mathrm{mL}$ in drinking water for 8 weeks [84]. The Cd-induced nephrotoxicity is understood to be mediated through the Cd-MT complex when it is uptaken by the renal proximal tubule resulting in tubular dysfunction promoting oxidative stress and genotoxicity [22].

In the same study by El-Refaiy and Eissa, other organs showing histopathological alterations after systemic Cd exposure are lungs and testicular tissue. It was reported that the lung tissue showed severe inflammation indicated by aggregation of lymphocyte infiltration including edema, thickening of interalveolar septa, enlargement of some air space, dilatation and congestion of pulmonary vein [83]. These changes was hypothesized to be a result of underlying Cd-induced oxidative stress [32] [83]. Damages to testicular tissues in the form of degeneration of spermatogenic cells, edema, hemorrhage, congestion and multifocal regions with ischemic necrosis was observed along with increased collagen fibers [83]. Studies reviewing the mechanisms by which $\mathrm{Cd}$ inflicts damage on the reproductive system showed that $\mathrm{Cd}$ can alter cell adhesion, induce oxidative stress and apoptosis, mimic ionic and molecular components and damage DNA consequently affecting the cell cycle [16] [17]. Histologically, these damages were indicated by disruption of blood-testis barrier, abnormal sperm morphology accompanied with disrupted blood-epididymal barrier, damaged endothelium in follicular blood vessels and necrosis in both testicular and ovarian tissues [16] [32] [85].

In bones, Cd exposure alters bone mineral density, histology and biomechanical properties. A study by Chen et al. reported severe damages to the proximal tibia of male Sprague Dawley rats treated with $1.5 \mathrm{mg} \mathrm{Cd} / \mathrm{kg}$ b.w. for 12 weeks inducing Itai-itai-like syndrome [86]. Authors reported a $20 \%-50 \%$ decrease in bone mineral density along with $30 \%-60 \%$ decrease in bone biomechanical property. Previously, Cd-induced bone damage was thought to be mediated through renal dysfunction such that primary damage is done to the kidneys and damage to the bones is a secondary effect [87]. However, in this study, the authors suggest that $\mathrm{Cd}$ intoxication can have a direct impact on the bone such that renal dysfunction and altered bone formation and reabsorption is caused simultaneously in relation to the dose of Cd exposure [86]. Another study showed histopathological alteration in bone marrow of albino Wistar rats treated with 15 $\mathrm{mg} \mathrm{Cd} / \mathrm{kg}$ b.w. manifested as an increase in adipocytes in bone marrow and decrease in the cellular portion [88]. These changes were attributed to the direct action of $\mathrm{Cd}$ on the bone cells thereby decreasing bone formation and increasing bone resorption [88] [89].

In 2010, Messner and Bernhard reviewed the molecular and biological mechanisms by which $\mathrm{Cd}$ affects the cardiovascular system thereby concluding the relevance of $\mathrm{Cd}$ as a novel and independent risk factor for cardiovascular pa- 
thologies [80]. In a study, male Wistar rats treated with $0.44 \mathrm{mg} \mathrm{Cd} / \mathrm{kg}$ b.w. every alternate day for 15 days found significant increase in the amount of $\mathrm{Cd}$ deposited in the heart $(4 \mu \mathrm{g} / \mathrm{g})$ and an increase in the levels of biomarkers of organ damage [90]. Histopathological analysis showed profound degeneration along with capillary dilatation, vascular congestion and necrosis of the myocardial fibers. This was further supported by the depletion of collagen fiber in cardiac tissue sections stained with picrosirius red indicating fibrosis in cardiac tissues. Also reported in the study was the crosslinking of myofibrillar collagen fibers forming an irregular branching pattern and complicated matrix network [90]. In addition to the cardiac tissues, Cd alters the aorta's histological integrity as evidenced by the induction of hypertrophic aortic wall remodeling by hyperplasia of smooth muscle cells, increased collagen deposition, decreased elastin and increased aortic medial wall matrix metalloproteinases [91]. Another study evaluating the histopathological changes in the heart of male albino rats treated with $200 \mathrm{mg} / \mathrm{L} \mathrm{Cd}$ for 8 weeks reported focal hyaline degeneration and perivascular fibrosis with narrowed lumen of cardiac blood vessels after 4 weeks, hyaline degeneration with focal areas of coagulative necrosis and interstitial fibrosis in the left ventricle after 8 weeks [92]. The results of these studies showed that $\mathrm{Cd}$ mediates tissue damage in the cardiovascular system by generating ROS inducing oxidative stress and inhibiting the expression of and depleting vital antioxidant enzymes [90] [91] [92].

An examination of effects of oral $\mathrm{Cd}$ exposure $(5 \mathrm{ppm}$ and $50 \mathrm{ppm}$ for 30-days) on skin immune reactivity by Tucovic et al. reported oxidative stress at both Cd doses, dose-dependent structural changes in the skin (dilation of sebaceous follicles, formation of vascular spaces, hyperkeratosis and hyper granulosis) and increased incidence of neutrophils and activated mast cells [76]. Ingested Cd was also shown to have an impact on the gastrointestinal tract histologically revealed as shorter and thicker villi with visible fusion of some villi and top-side necrosis [75]. Dose-dependent prominence of goblet-cell like vacuoles and infiltration of inflammatory cells was observed consisting mainly of lymphocytes [75].

The studies presented thus far demonstrates that $\mathrm{Cd}$ exposure at different doses ranging from $0.44 \mathrm{mg} / \mathrm{kg}$ b.w. up to $200 \mathrm{mg} / \mathrm{kg}$ b.w. targets multiple organ systems by inducing systemic oxidative stress, tissue inflammation and consequently tissue damage. The extent of damage to the tissue (such as altered histological architecture, fibrosis, necrosis, apoptosis) as a result of $\mathrm{Cd}$ exposure is dependent on the dose and duration of exposure.

\section{Conclusion}

Cadmium is a xenobiotic with rising concern to public health due to its ability to inflict damage on different organ systems depending on dose, route of exposure and duration of exposure. Various pathologies have been associated with Cd-induced oxidative stress that interacts with the inflammatory response either as a primary mechanism or a secondary mechanism (Figure 3 ). In both 


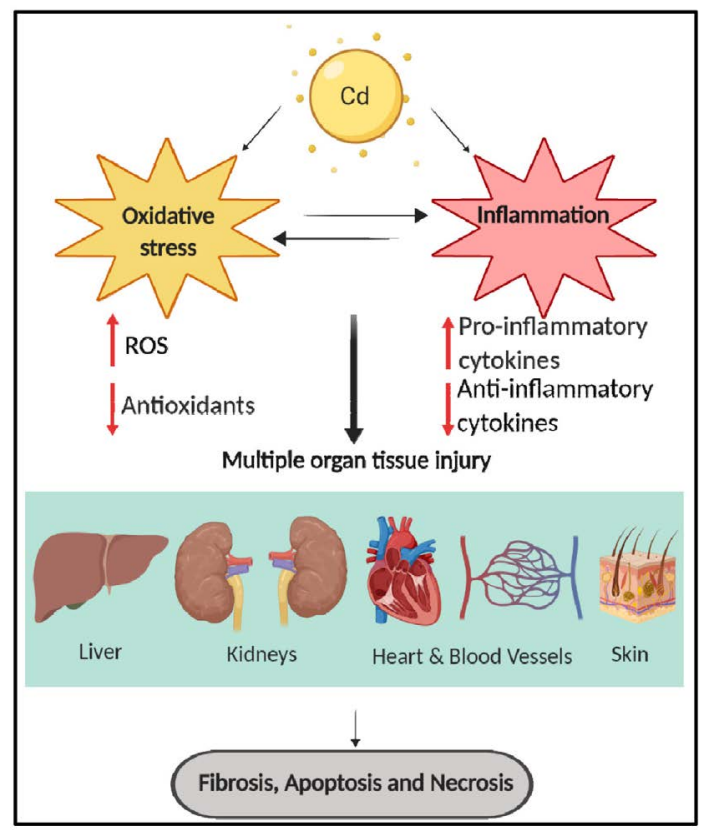

Figure 3. Illustration summarizing the impact of cadmium toxicity leading to multi-organ tissue injury (Created by biorender.com).

scenarios, there are two key steps that involve inflammation namely, the activation of NF- $\kappa \mathrm{B}$ and the release of cytokines. While accumulating literature shows variable extent of pro-inflammatory response at the level of gene expression and production to $\mathrm{Cd}$ exposure, some studies have also shown the opposite. It is worth noting that these contradictions can be attributed to the biological system, exposure route and dose used in the different experimental setups. Taken together, these studies support the notion that $\mathrm{Cd}$ is associated with oxidative stress and inflammation leading to multi-organ tissue injury in the body. Currently, the role of NF- $\kappa \mathrm{B}$ is being widely reviewed as a common player in inflammation and oxidative stress [68] [93] [94]. Perhaps further research targeting signals upstream of NF- $\kappa \mathrm{B}$ could help understand the role of Cd toxicity and prevent the inflicting of damages to the tissue while preventing the overwhelming of the oxidative stress and inflammatory response.

\section{Conflicts of Interest}

The authors declare no conflicts of interest regarding the publication of this paper.

\section{References}

[1] Tolcin, A.C. (2016) Cadmium. In: Mineral Commodity Summaries 2016, U.S. Government Publishing Office, Washington DC, 42-43.

[2] Lamb, D.T., Kader, M., Ming, H., Wang, L., Abbasi, S., Megharaj, M., et al. (2016) Predicting Plant Uptake of Cadmium: Validated with Long-Term Contaminated Soils. Ecotoxicology, 25, 1563-1574. https://doi.org/10.1007/s10646-016-1712-0

[3] Solenkova, N.V., Newman, J.D., Berger, J.S., Thurston, G., Hochman, J.S. and Lamas, G.A. 
(2014) Metal Pollutants and Cardiovascular Disease: Mechanisms and Consequences of Exposure. American Heart Journal, 168, 812-822.

https://doi.org/10.1016/j.ahj.2014.07.007

[4] WHO (2011) Cadmium in Drinking Water [Internet].

[5] Faroon, O., Ashizawa, A., Wright, S., Tucker, P., Jenkins, K., Ingerman, L., et al. (2012) Toxicological Profile for Cadmium [Internet]. Agency for Toxic Substances and Disease Registry (US), Atlanta.

[6] United States Environmental Protection Agency and EPA (2014) Priority Pollutant List [Internet].

[7] IARC (2012) Cadmium and Cadmium Compounds. IARC Monographs on the Evaluation of Carcinogenic Risks to Humans, IARC, 121-145.

[8] WHO (2003) Cadmium Review [Internet].

[9] Zang, Y., Devleesschauwer, B., Bolger, P.M., Goodman, E. and Gibb, H.J. (2019) Global Burden of Late-Stage Chronic Kidney Disease Resulting from Dietary Exposure to Cadmium, 2015. Environmental Research, 169, 72-78.

https://doi.org/10.1016/j.envres.2018.10.005

[10] Agnihotri, S.K., Agrawal, U. and Ghosh, I. (2015) Brain Most Susceptible to Cadmium Induced Oxidative Stress in Mice. Journal of Trace Elements in Medicine and Biology, 30, 184-193. https://doi.org/10.1016/j.jtemb.2014.12.008

[11] Ozturk, I.M., Buyukakilli, B., Balli, E., Cimen, B., Gunes, S. and Erdogan, S. (2009) Determination of Acute and Chronic Effects of Cadmium on the Cardiovascular System of Rats. Toxicology Mechanisms and Methods, 19, 308-317. https://doi.org/10.1080/15376510802662751

[12] Ghosh, K. and N, I. (2018) Cadmium Treatment Induces Echinocytosis, DNA Damage, Inflammation, and Apoptosis in Cardiac Tissue of Albino Wistar Rats. Environmental Toxicology and Pharmacology, 59, 43-52. https://doi.org/10.1016/j.etap.2018.02.009

[13] Alessandria, I., Pennisi, M., Cataudella, E., Frazzetto, P.M., Malaguarnera, M., Rampello, L., et al. (2012) Neurotoxicity in Cadmium-Exposed Workers. Acta Medica Mediterranea, 28, 253-256.

[14] Marth, E., Barth, S. and Jelovcan, S. (2000) Influence of Cadmium on the Immune System. Description of Stimulating Reactions. Central European Journal of Public Health, 8, 40-44.

[15] Tinkov, A.A., Gritsenko, V.A., Skalnaya, M.G., Cherkasov, S.V., Aaseth, J. and Skalny, A.V. (2018) Gut as a Target for Cadmium Toxicity. Environmental Pollution, 235, 429-434. https://doi.org/10.1016/j.envpol.2017.12.114

[16] Thompson, J. and Bannigan, J. (2008) Cadmium: Toxic Effects on the Reproductive System and the Embryo. Reproductive Toxicology, 25, 304-315. https://doi.org/10.1016/j.reprotox.2008.02.001

[17] de Angelis, C., Galdiero, M., Pivonello, C., Salzano, C., Gianfrilli, D., Piscitelli, P., et al. (2017) The Environment and Male Reproduction: The Effect of Cadmium Exposure on Reproductive Function and Its Implication in Fertility. Reproductive Toxicology, 73, 105-127. https://doi.org/10.1016/j.reprotox.2017.07.021

[18] Nishijo, M., Nakagawa, H., Suwazono, Y., Nogawa, K. and Kido, T. (2017) Causes of Death in Patients with Itai-Itai Disease Suffering from Severe Chronic Cadmium Poisoning: A Nested Case-Control Analysis of a Follow-Up Study in Japan. BMJ Open, 7, e015694. https://doi.org/10.1136/bmjopen-2016-015694

[19] Olszowski, T., Baranowska-Bosiacka, I., Gutowska, I. and Chlubek, D. (2012) Pro-Inflammatory Properties of Cadmium. Acta Biochimica Polonica, 59, 475-482. https://doi.org/10.18388/abp.2012 2080

[20] Matović, V., Dukić-Ćosić, D., Buha, A. and Bulat, Z. (2013) Route, Dose and Duration of Exposure to Cadmium-Relevance to Oxidative Stress Induction. In: Bogaert, L. and Coppens, N., Eds., Peroxidases. Biochemical Characteristics, Functions and Potential Applications, Nova Science Publishers, Inc., Hauppauge, 159-175. 
[21] Chatterjee, S. (2016) Oxidative Stress, Inflammation, and Disease. In: Oxidative Stress and Biomaterials, Elsevier, Amsterdam, 35-58. https://doi.org/10.1016/B978-0-12-803269-5.00002-4

[22] Rashid, K., Sinha, K. and Sil, P.C. (2013) An Update on Oxidative Stress-Mediated Organ Pathophysiology. Food and Chemical Toxicology, 62, 584-600. https://doi.org/10.1016/j.fct.2013.09.026

[23] Sies, H. (1997) Oxidative Stress: Oxidants and Antioxidants. Experimental Physiology, 82, 291-295. https://doi.org/10.1113/expphysiol.1997.sp004024

[24] Liu, J., Qu, W. and Kadiiska, M.B. (2009) Role of Oxidative stress in Cadmium Toxicity and Carcinogenesis. Toxicology and Applied Pharmacology, 238, 209-214. https://doi.org/10.1016/j.taap.2009.01.029

[25] Sies, H. (2018) On the History of Oxidative Stress: Concept and Some Aspects of Current Development. Current Opinion in Toxicology, 7, 122-126. https://doi.org/10.1016/j.cotox.2018.01.002

[26] Burton, G.J. and Jauniaux, E. (2011) Oxidative Stress. Best Practice \& Research Clinical Obstetrics \& Gynaecology, 25, 287-299. https://doi.org/10.1016/j.bpobgyn.2010.10.016

[27] Cuypers, A., Plusquin, M., Remans, T., Jozefczak, M., Keunen, E., Gielen, H., et al. (2010) Cadmium Stress: An Oxidative Challenge. BioMetals, 23, 927-940. https://doi.org/10.1007/s10534-010-9329-x

[28] Patra, R.C., Rautray, A.K. and Swarup, D. (2011) Oxidative Stress in Lead and Cadmium Toxicity and Its Amelioration. Veterinary Medicine International, 2011, Article ID: 457327. https://doi.org/10.4061/2011/457327

[29] Gagné, F. (2014) Oxidative Stress. In: Biochemical Ecotoxicology, Elsevier, Amsterdam, 103-115. https://doi.org/10.1016/B978-0-12-411604-7.00006-4

[30] Wang, J., Zhang, P., Shen, Q., Wang, Q., Liu, D., Li, J., et al. (2013) The Effects of Cadmium Exposure on the Oxidative State and Cell Death in the Gill of Freshwater Crab Sinopotamon Henanense. PLOS ONE, 8, e64020. https://doi.org/10.1371/journal.pone.0064020

[31] Rani, A., Kumar, A., Lal, A. and Pant, M. (2014) Cellular Mechanisms of Cadmium-Induced Toxicity: A Review. International Journal of Environmental Health Research, 24, 378-399. https://doi.org/10.1080/09603123.2013.835032

[32] Nair, A., DeGheselle, O., Smeets, K., Van Kerkhove, E. and Cuypers, A. (2013) Cadmium-Induced Pathologies: Where Is the Oxidative Balance Lost (or Not)? International Journal of Molecular Sciences, 14, 6116-6143. https://doi.org/10.3390/ijms14036116

[33] Rikans, L.E. and Yamano, T. (2000) Mechanisms of Cadmium-Mediated Acute Hepatotoxicity. Journal of Biochemical and Molecular Toxicology, 14, 110-117. https://doi.org/10.1002/(SICI)1099-0461(2000)14:2<110::AID-JBT7>3.0.CO;2-I

[34] Matović, V., Buha, A., Bulat, Z., Đukić-Ćosić, D., Miljković, M., Ivanišević, J., et al. (2012) Route-Dependent Effects of Cadmium/Cadmium and Magnesium Acute Treatment on Parameters of Oxidative Stress in Rat Liver. Food and Chemical Toxicology, 50, 552-557. https://doi.org/10.1016/j.fct.2011.12.035

[35] Liu, L., Tao, R., Huang, J., He, X., Qu, L., Jin, Y., et al. (2015) Hepatic Oxidative Stress and Inflammatory Responses with Cadmium Exposure in Male Mice. Environmental Toxicology and Pharmacology, 39, 229-236. https://doi.org/10.1016/j.etap.2014.11.029

[36] Abdel-Moneim, A.M. and Said, K.M. (2007) Acute Effect of Cadmium Treatment on the Kidney of Rats: Biochemical and Ultrastructural Studies. Pakistan Journal of Biological Sciences, 10, 3497-3506. https://doi.org/10.3923/pjbs.2007.3497.3506

[37] Alese, M.O., Agbaje, M.A. and Alese, O.O. (2018) Cadmium Induced Damage in Wistar Rats, Ameliorative Potentials of Progesterone. Journal of Trace Elements in Medicine and Biology, 50, 276-282. https://doi.org/10.1016/j.jtemb.2018.07.014 
[38] Ferramola, M.L., Pérez Díaz, M.F.F., Honoré, S.M., Sánchez, S.S., Antón, R.I., Anzulovich, A.C., et al. (2012) Cadmium-Induced Oxidative Stress and Histological Damage in the Myocardium. Effects of a Soy-Based Diet. Toxicology and Applied Pharmacology, 265, 380-389. https://doi.org/10.1016/j.taap.2012.09.009

[39] Alghasham, A., Salem, T.A. and Meki, A.-R.M. (2013) Effect of Cadmium-Polluted Water on Plasma Levels of Tumor Necrosis Factor- $\alpha$, Interleukin- 6 and Oxidative Status Biomarkers in Rats: Protective Effect of Curcumin. Food and Chemical Toxicology, 59, 160-164. https://doi.org/10.1016/j.fct.2013.05.059

[40] Abu-El-Zahab, H.S.H., Hamza, R.Z., Montaser, M.M., El-Mahdi, M.M. and Al-Harthi, W.A. (2019) Antioxidant, Antiapoptotic, Antigenotoxic, and Hepatic Ameliorative Effects of L-Carnitine and Selenium on Cadmium-Induced Hepatotoxicity and Alterations in Liver Cell Structure in Male Mice. Ecotoxicology and Environmental Safety, 173, 419-428. https://doi.org/10.1016/j.ecoenv.2019.02.041

[41] Salama, S.A., Arab, H.H., Hassan, M.H., Al robaian, M.M. and Maghrabi, I.A. (2019) Cadmium-Induced Hepatocellular Injury: Modulatory Effects of $\gamma$-Glutamyl Cysteine on the Biomarkers of Inflammation, DNA Damage, and Apoptotic Cell Death. Journal of Trace Elements in Medicine and Biology, 52, 74-82. https://doi.org/10.1016/j.jtemb.2018.12.003

[42] Cho, M.-R., Kang, H.-G., Jeong, S.-H. and Cho, M.-H. (2010) Time-Dependent Changes of Cadmium and Metallothionein after Short-Term Exposure to Cadmium in Rats. Toxicological Research, 26, 131-136. https://doi.org/10.5487/TR.2010.26.2.131

[43] Benjamini, E., Coico, R. and Sunshine, G. (2000) Elements of Innate and Acquired Immunity. In: Immunology, 4th Edition, Wiley-Liss Inc., New York, 24.

[44] Ptaschinski, C. and Lukacs, N.W. (2018) Acute and Chronic Inflammation Induces Disease Pathogenesis. In: Molecular Pathology, 2nd Edition, Elsevier, Amsterdam, 25-43. https://doi.org/10.1016/B978-0-12-802761-5.00002-X

[45] Abdulkhaleq, L.A., Assi, M.A., Abdullah, R., Zamri-Saad, M., Taufiq-Yap, Y.H. and Hezmee, M.N.M. (2018) The Crucial Roles of Inflammatory Mediators in Inflammation: A Review. Veterinary World, 11, 627-635. https://doi.org/10.14202/vetworld.2018.627-635

[46] Biswas, S.K. (2016) Does the Interdependence between Oxidative Stress and Inflammation Explain the Antioxidant Paradox? Oxidative Medicine and Cellular Longevity, 2016, Article ID: 5698931. https://doi.org/10.1155/2016/5698931

[47] Apostolakis, S., Vogiatzi, K., Amanatidou, V. and Spandidos, D.A. (2009) Interleukin 8 and Cardiovascular Disease. Cardiovascular Research, 84, 353-360. https://doi.org/10.1093/cvr/cvp241

[48] Brat, D.J., Bellail, A.C. and Van Meir, E.G. (2005) The Role of Interleukin-8 and Its Receptors in Gliomagenesis and Tumoral Angiogenesis. Neuro-Oncology, 7, 122-133. https://doi.org/10.1215/S1152851704001061

[49] Phuagkhaopong, S., Ospondpant, D., Kasemsuk, T., Sibmooh, N., Soodvilai, S., Power, C., et al. (2017) Cadmium-Induced IL-6 and IL-8 Expression and Release from Astrocytes Are Mediated by MAPK and NF- $\kappa$ B Pathways. NeuroToxicology, 60, 82-91. https://doi.org/10.1016/j.neuro.2017.03.001

[50] Cormet-Boyaka, E., Jolivette, K., Bonnegarde-Bernard, A., Rennolds, J., Hassan, F., Mehta, P., et al. (2012) An NF- $\kappa \mathrm{B}$-Independent and Erk1/2-Dependent Mechanism Controls CXCL8/IL-8 Responses of Airway Epithelial Cells to Cadmium. Toxicological Sciences, 125, 418-429. https://doi.org/10.1093/toxsci/kfr310

[51] Benveniste, E.N. (2014) Cytokines. In: Encyclopedia of the Neurological Sciences, Elsevier, Amsterdam, 921-925. https://doi.org/10.1016/B978-0-12-385157-4.00175-5

[52] Afolabi, O.K., Oyewo, E.B., Adekunle, A.S., Adedosu, O.T. and Adedeji, A.L. (2012) Impaired Lipid Levels and Inflammatory Response in Rats Exposed to Cadmium. EXCLI Journal, 11, 677-687.

[53] Nazimabashir, Manoharan, V. and Miltonprabu, S. (2015) Cadmium Induced Cardiac Oxida- 
tive Stress in Rats and Its Attenuation by GSP through the Activation of Nrf2 Signaling Pathway. Chemico-Biological Interactions, 242, 179-193.

https://doi.org/10.1016/j.cbi.2015.10.005

[54] Riemschneider, S., Herzberg, M. and Lehmann, J. (2015) Subtoxic Doses of Cadmium Modulate Inflammatory Properties of Murine RAW 264.7 Macrophages. BioMed Research International, 2015, Article ID: 295303. https://doi.org/10.1155/2015/295303

[55] Låg, M., Rodionov, D., Øvrevik, J., Bakke, O., Schwarze, P.E. and Refsnes, M. (2010) Cadmium-Induced Inflammatory Responses in Cells Relevant for Lung Toxicity: Expression and Release of Cytokines in Fibroblasts, Epithelial Cells and Macrophages. Toxicology Letters, 193, 252-260. https://doi.org/10.1016/j.toxlet.2010.01.015

[56] Mosser, D.M. and Zhang, X. (2008) Interleukin-10: New Perspectives on an Old Cytokine. Immunological Reviews, 226, 205-218. https://doi.org/10.1111/j.1600-065X.2008.00706.x

[57] Tracey, K.J. (2002) The Inflammatory Reflex. Nature, 420, 853-859. https://doi.org/10.1038/nature01321

[58] Monin, L. and Gaffen, S.L. (2018) Interleukin 17 Family Cytokines: Signaling Mechanisms, Biological Activities, and Therapeutic Implications. Cold Spring Harbor Perspectives in Biology, 10, a028522. https://doi.org/10.1101/cshperspect.a028522

[59] Demenesku, J., Mirkov, I., Ninkov, M., Popov Aleksandrov, A., Zolotarevski, L., Kataranovski, D., et al. (2014) Acute Cadmium Administration to Rats Exerts Both Immunosuppressive and Proinflammatory Effects in Spleen. Toxicology, 326, 96-108. https://doi.org/10.1016/j.tox.2014.10.012

[60] Lifshitz, V. and Frenkel, D. (2013) TGF- $\beta$. In: Handbook of Biologically Active Peptides, Elsevier, Amsterdam, 1647-1653. https://doi.org/10.1016/B978-0-12-385095-9.00225-6

[61] Baroni, T., Lilli, C., Bellucci, C., Luca, G., Mancuso, F., Fallarino, F., et al. (2015) In Vitro Cadmium Effects on ECM Gene Expression in Human Bronchial Epithelial Cells. Cytokine, 72, 9-16. https://doi.org/10.1016/j.cyto.2014.12.002

[62] Lawrence, T. (2009) The Nuclear Factor NF-kappaB Pathway in Inflammation. Cold Spring Harbor Perspectives in Biology, 1, a001651. https://doi.org/10.1101/cshperspect.a001651

[63] Baker, R.G., Hayden, M.S. and Ghosh, S. (2011) NF- $\kappa$ B, Inflammation, and Metabolic Disease. Cell Metabolism, 13, 11-22. https://doi.org/10.1016/j.cmet.2010.12.008

[64] Wong, E.T. and Tergaonkar, V. (2009) Roles of NF- $\kappa$ B in Health and Disease: Mechanisms and Therapeutic Potential. Clinical Science, 116, 451-465. https://doi.org/10.1042/CS20080502

[65] Kumar, A., Takada, Y., Boriek, A. and Aggarwal, B. (2004) Nuclear Factor-kappaB: Its Role in Health and Disease. Journal of Molecular Medicine, 82, 434-448. https://doi.org/10.1007/s00109-004-0555-y

[66] Chen, F. and Shi, X. (2002) Signaling from Toxic Metals to NF-kappaB and Beyond: Not Just a Matter of Reactive Oxygen Species. Environmental Health Perspectives, 110, 807-811. https://doi.org/10.1289/ehp.02110s5807

[67] Morgan, M.J. and Liu, Z. (2011) Crosstalk of Reactive Oxygen Species and NF- $\kappa$ B Signaling. Cell Research, 21, 103-115. https://doi.org/10.1038/cr.2010.178

[68] Lingappan, K. (2018) NF- $\kappa$ B in Oxidative Stress. Current Opinion in Toxicology, 7, 81-86. https://doi.org/10.1016/j.cotox.2017.11.002

[69] Papa, S., Zazzeroni, F., Pham, C.G., Bubici, C. and Franzoso, G. (2004) Linking JNK Signaling to NF-B: A Key to Survival. Journal of Cell Science, 117, 5197-5208. https://doi.org/10.1242/jcs.01483

[70] Moulis, J.-M. and Thévenod, F. (2010) New Perspectives in Cadmium Toxicity: An Introduction. BioMetals, 23, 763-768. https://doi.org/10.1007/s10534-010-9365-6 
[71] Zhang, H., Li, L., Wang, Y., Dong, F., Chen, X., Liu, F., et al. (2016) NF- $\kappa$ B Signaling Maintains the Survival of Cadmium-Exposed Human Renal Glomerular Endothelial Cells. International Journal of Molecular Medicine, 38, 417-422. https://doi.org/10.3892/ijmm.2016.2640

[72] Hoffmann, E., Dittrich-Breiholz, O., Holtmann, H. and Kracht, M. (2002) Multiple Control of Interleukin-8 Gene Expression. Journal of Leukocyte Biology, 72, 847-855.

[73] Djokic, J., Ninkov, M., Mirkov, I., Popov Aleksandrov, A., Zolotarevski, L., Kataranovski, D., et al. (2014) Differential Effects of Cadmium Administration on Peripheral Blood Granulocytes in Rats. Environmental Toxicology and Pharmacology, 37, 210-219. https://doi.org/10.1016/j.etap.2013.11.026

[74] Djokic, J., Popov Aleksandrov, A., Ninkov, M., Mirkov, I., Zolotarevski, L., Kataranovski, D., et al. (2015) Cadmium Administration Affects Circulatory Mononuclear Cells in Rats. Journal of Immunotoxicology, 12, 115-123. https://doi.org/10.3109/1547691X.2014.904955

[75] Ninkov, M., Popov Aleksandrov, A., Demenesku, J., Mirkov, I., Mileusnic, D., Petrovic, A., et al. (2015) Toxicity of Oral Cadmium Intake: Impact on Gut Immunity. Toxicology Letters, 237, 89-99. https://doi.org/10.1016/j.toxlet.2015.06.002

[76] Tucovic, D., Popov Aleksandrov, A., Mirkov, I., Ninkov, M., Kulas, J., Zolotarevski, L., et al. (2018) Oral Cadmium Exposure Affects Skin Immune Reactivity in Rats. Ecotoxicology and Environmental Safety, 164, 12-20. https://doi.org/10.1016/j.ecoenv.2018.07.117

[77] Bonaventura, P., Courbon, G., Lamboux, A., Lavocat, F., Marotte, H., Albarède, F., et al. (2017) Protective Effect of Low Dose Intra-Articular Cadmium on Inflammation and Joint Destruction in Arthritis. Scientific Reports, 7, Article No. 2415. https://doi.org/10.1038/s41598-017-02611-5

[78] Bonaventura, P., Lamboux, A., Albarède, F. and Miossec, P. (2017) Regulatory Effects of Zinc on Cadmium-Induced Cytotoxicity in Chronic Inflammation. PLoS ONE, 12, e0180879. https://doi.org/10.1371/journal.pone.0180879

[79] Bernhard, D., Rossmann, A., Henderson, B., Kind, M., Seubert, A. and Wick, G. (2006) Increased Serum Cadmium and Strontium Levels in Young Smokers. Arteriosclerosis, Thrombosis, and Vascular Biology, 26, 833-838. https://doi.org/10.1161/01.ATV.0000205616.70614.e5

[80] Messner, B. and Bernhard, D. (2010) Cadmium and Cardiovascular Diseases: Cell Biology, Pathophysiology, and Epidemiological Relevance. BioMetals, 23, 811-822. https://doi.org/10.1007/s10534-010-9314-4

[81] Szuster-Ciesielska, A., Łokaj, I. and Kandefer-Szerszeń, M. (2000) The Influence of Cadmium and Zinc Ions on the Interferon and Tumor Necrosis Factor Production in Bovine Aorta Endothelial Cells. Toxicology, 145, 135-145. https://doi.org/10.1016/S0300-483X(00)00147-5

[82] Alkushi, A.G., Sinna, M.M., EL-Hady, M. and ElSawy, N.A. (2018) Structural Changes in Adult Rat Liver Following Cadmium Treatment. Pakistan Journal of Nutrition, 17, 89-101. https://doi.org/10.3923/pjn.2018.89.101

[83] El-Refaiy, A.I. and Eissa, F.I. (2013) Histopathology and Cytotoxicity as Biomarkers in Treated Rats with Cadmium and Some Therapeutic Agents. Saudi Journal of Biological Sciences, 20, 265-280. https://doi.org/10.1016/j.sjbs.2013.02.004

[84] Chwełatiuk, E., Włostowski, T., Krasowska, A. and Bonda, E. (2006) The Effect of Orally Administered Melatonin on Tissue Accumulation and Toxicity of Cadmium in Mice. Journal of Trace Elements in Medicine and Biology, 19, 259-265. https://doi.org/10.1016/j.jtemb.2005.10.006

[85] Sarkar, A., Pilani, B., Goa, B., Ravindran, G. and Krishnamurthy, V. (2013) A Brief Review on the Effect of Cadmium Toxicity: From Cellular to Organ Level. International Journal of Bio-Technology and Research, 3, 17-36.

[86] Chen, X., Zhu, G., Jin, T., Gu, S., Tan, M., Xiao, H., et al. (2011) Cadmium Exposure Induced Itai-Itai-Like Syndrome in Male Rats. Open Medicine, 6, 425-434. https://doi.org/10.2478/s11536-011-0046-9 
[87] Berglund, M., Akesson, A., Bjellerup, P. and Vahter, M. (2000) Metal-Bone Interactions. Toxicology Letters, 112-113, 219-225.

https://doi.org/10.1016/S0378-4274(99)00272-6

[88] Ramesh, G., Madhuri, D., Lakshman, M. and Reddy, A.G. (2018) Histopathological Changes in Bone Marrow Induced by Lead and Cadmium Alone and Combined Exposure in Male Wistar Rats. Journal of Entomology and Zoology Studies, 6, 3035-3037.

[89] Nawrot, T.S., Staessen, J.A., Roels, H.A., Munters, E., Cuypers, A., Richart, T., et al. (2010) Cadmium Exposure in the Population: From Health Risks to Strategies of Prevention. BioMetals, 23, 769-782. https://doi.org/10.1007/s10534-010-9343-Z

[90] Bhattacharjee, B., Pal, P.K., Ghosh, A.K., Mishra, S., Chattopadhyay, A. and Bandyopadhyay, D. (2019) Aqueous Bark Extract of Terminalia arjuna Protects against Cadmium-Induced Hepatic and Cardiac Injuries in Male Wistar Rats through Antioxidative Mechanisms. Food and Chemical Toxicology, 124, 249-264. https://doi.org/10.1016/j.fct.2018.12.008

[91] Sangartit, W., Kukongviriyapan, U., Donpunha, W., Pakdeechote, P., Kukongviriyapan, V., Surawattanawan, P., et al. (2014) Tetrahydrocurcumin Protects against Cadmium-Induced Hypertension, Raised Arterial Stiffness and Vascular Remodeling in Mice. PLoS ONE, 9, e114908. https://doi.org/10.1371/journal.pone.0114908

[92] Saleh, R.M. and Awadin, W.F. (2017) Biochemical and Histopathological Changes of Subacute Cadmium Intoxication in Male Rats. Environmental Science and Pollution Research, 24, 25475-25481. https://doi.org/10.1007/s11356-017-0348-9

[93] Liu, T., Zhang, L., Joo, D. and Sun, S.-C. (2017) NF- $\kappa$ B Signaling in Inflammation. Signal Transduction and Targeted Therapy, 2, e17023. https://doi.org/10.1038/sigtrans.2017.23

[94] Bubici, C., Papa, S., Dean, K. and Franzoso, G. (2006) Mutual Cross-Talk between Reactive Oxygen Species and Nuclear Factor-kappaB: Molecular Basis and Biological Significance. Oncogene, 25, 6731-6748. https://doi.org/10.1038/sj.onc.1209936 